\title{
Analisis Potensi Community Based Tourism Daya Tarik Wisata Tebing Koja
}

\section{Nova Sitorus}

Pradita University Tangerang, Banten, Indonsia

nova.irene@pradita.ac.id

\begin{abstract}
ABSTRAK
Pendekatan masyarakat (community approach) menjadi standar baku bagi proses pengembangan pariwisata di daerah pinggiran, dimana melibatkan masyarakat di dalamnya merupakan faktor yang sangat penting untuk menghasilkan kesuksesan terhadap produk wisata. Pariwisata berbasis kemasyarakatan atau Community Based Tourism merupakan salah satu konsep pengembangan suatu destinasi wisata lokal dimana masyarakat yang ada turut andil dalam perencanaan, pengelolaan dan juga memberi suara berupa keputusan dalam pembangunannya (Arifin, 2017). Berdasarkan pemaparan, tujuan dari penelitian ini adalh untuk mengetahui potensi community based tourism di Daya Tarik Wisata Tebing Koja.

Jenis penelitian yang tim peneliti gunakan dalam penelitian ini adalah penelitian deskriptif kualitatif. Menurut Bogdan dan Taylor "metode kualitatif" sebagai prosedur penelitian yang menghadirkan data deskriptif beberapa kata kata tertulis atau lisan dari orang-orang atau pelaku yang dapat diamati (Moleong, 2018). Metode pengumpulan data yang digunakan pada penelitian pengembangan aktivitas wisata di Tebing Koja dilakukan dengan cara wawancara. Tim penulis melakukan wawancara secara mendalam terhadap partisipan kunci yaitu pemilik asli dari objek wisata Tebing Koja. Daya tarik wisata Tebing Koja masih membutuhkan banyak perbaikan dan pengembangan. Adapun potensi community based tourism di Daya Tarik Wisata Tebing Koja ini dapat dikembangkan dengan memberdayakan masyarakat sekitar.
\end{abstract}

\section{ARTICLE HISTORY}

Submitted :10.11.2021

Revised : 20.11 .2021

Accepted :04.01.2022

Online first :05.01.2022

\section{KATA KUNCI}

Potensi wisata, community-based tourism, daya tarik wisata 


\section{Pendahuluan}

Sektor pariwisata merupakan penghasil devisa negara yang cukup tinggi karena sektor pariwisata mendatangkan wisatawan dari berbagai negara. Pada tahun 2019 jumlah wisatawan ke Indonesia mencapai 16,11jt kunjungan. Menurut data dari BPS (Badan Pusat Statistik) tingkat kunjungan wisman ke Indonesia naik sebanyak 1,88\%, jika dibandingkan dengan tahun 2018, 2020 jumlah kunjungan wisman ke Indonesia hanya berjumlah 15,81jt kunjungan (Badan Pusat Statistik, 2020). Dari data tersebut terlihat bahwa sektor pariwisata Indonesia sedang berkembang. Tidak terkecuali di Kabupaten Tangerang. Kabupaten Tangerang sendiri memiliki peluang yang sangat besar dalam sektor pariwisata karena pertumbuhan penduduk di daerah ini cukup pesat. Berdasarkan data statistik penduduk Kabupaten Tangerang tahun 2020 (Departemen kependudukan dan pencatatan sipil Kabupaten Tangerang, 2020) dapat diketahui bahwa jumlah penduduk Kabupaten Tangerang terus mengalami peningkatan dari tahun 2018 hingga tahun 2020. Laju pertumbuhan penduduk Kabupaten Tangerang pada tahun 2019 sebesar 1,04 dan pada tahun 2020 meningkat kembali sebesar 5,86\% atau meningkat sebanyak 328.945 orang jika dibandingkan pada tahun 2018 (Statistik Kependudukan Kabupaten Tangerang Tahun 2020, 2021) . Sehingga, Kabupaten Tangerang memiliki potensi pariwisata yang cukup besar, dimana objek wisata di sekitar Kabupaten Tangerang akan banyak diminati oleh wisatawan domestik.

Salah satu objek wisata yang ada di Kabupaten Tangerang adalah Tebing Koja, yang berlokasi di Desa Cikuya, Kecamatan Solear, Kabupaten Tangerang. Tebing Koja merupakan tebing yang terbentuk akibat dari penambangan pasir yang dilakukan masyarakat setempat dan sudah tidak beroperasi. Sisa dari penambangan pasir tersebut menciptakan tebing kapur yang menjulang tinggi dan pada bagian bawah tebing terdapat genangan air yang membuatnya terlihat indah. Terdapat spot fotoyang menjadi favorit pengunjung yaitu Kandang Godzilla, yang merupakan tebing yang menyerupai dari hewan purba tersebut. Hal ini menjadi salah satu alasan wisatawan mengunjungi Tebing Koja selain pemandangannya yang indah. Masyarakat sekitar sebagai halnya komponen penting dalam pengembangan berbasis masyarakat, sudah pasti mempunyai peranan penting dalam menunjang pengembangan wisata daerah dimana mengembangkan potensi lokal yang bersumber dari alam, sosial, budaya maupun ekonomi masyarakat. Dalam UU No 9 Tahun 1990 tentang Kepariwisataan, masyarakat sekitar memiliki peluang yang sama dan sebesar-besarnya dalam ikut serta pengembangan kepariwisataan ini. Peran serta masyarakat sekitar dalam 
Edutourism Journal of Tourism Research I p-ISSN: 2686-4746 I e-ISSN: 2721-1371

menjaga dan memelihara sumber daya alam dan budaya yang ada merupakan andil yang besar sehingga berpotensi untuk daya tarik wisata lebih berkembang (Purba, 2017).

Menurut Barreto dan Giantari (2015: 11 ) pengembangan pariwisata merupakan suatu upaya untuk memajukan sebuah objek wisata agar objek wisata tersebut menjadi lebih baik dan lebih menarik jika dilihat dari segi lokasi, dan semua yang ada di dalam objek wisata tersebut sehingga dapat menarik minat wisatawan untuk mengunjungi objek wisata tersebut. Pengembangan sebuah daerah yang menjadi tujuan wisata sangat erat hubungannya dengan pembangunan perekonomian suatu daerah atau suatu negara. Maka dari itu, pengembangan wisata merupakan alasan utama sebuah daerah tujuan wisata terus dikembangkan (Adikampana, 2017).

Pendekatan masyarakat (community approach) menjadi standar baku bagi proses pengembangan pariwisata di daerah pinggiran, dimana melibatkan masyarakat di dalamnya merupakan faktor yang sangat penting untuk menghasilkan kesuksesan terhadap produk wisata. Pariwisata berbasis kemasyarakatan atau Community Based Tourism merupakan salah satu konsep pengembangan suatu destinasi wisata lokal dimana masyarakat yang ada turut andil dalam perencanaan, pengelolaan dan juga memberi suara berupa keputusan dalam pembangunannya (Arifin, 2017). Berdasarkan pemaparan, tujuan dari penelitian ini adalh untuk mengetahui potensi community based tourism di Daya Tarik Wisata Tebing Koja.

\section{Kajian Teori}

Menurut Spillane (1987 : 20) Pariwisata adalah perjalanan dari suatu tempat ke tempat yang lain dan bersifat sementara, dilakukan secara perorangan atau berkelompok yang bertujuan sebagai usaha mencari keseimbangan, keasrian dan kebahagiaan dengan lingkungan hidup dalam dimensi sosial, budaya, alam dan ilmu. Pariwisata merupakan salah satu industri terbesar yang sedang berkembang pesat di dunia. Indonesia memiliki kekayaan alam, budaya dan adat istiadat yang berbeda-beda dan menjadikan suatu modal utama dalam kepariwisataan (Firawan \& Suryawan, 2016).

Menurut A, Yoeti dalam bukunya “Pengantar Ilmu Pariwisata” menyatakan bahwa Tourist Attraction atau daya tarik wisata merupakan segala sesuatu yang menjadi suatu daya tarik bagi orang yang berkunjung ke suatu daerah tertentu. Menurut I Gusti Bagus Rai Utama (2016:142) Daya tarik wisata merupakan segala sesuatu yang menarik dan mempunyai nilai untuk dilihat dan dikunjungi, juga memiliki keunikan, keindahan, serta nilai yang berwujud keanekaragaman kekayaan alam maupun buatan manusia yang menarik. 
Edutourism Journal of Tourism Research I p-ISSN: 2686-4746 I e-ISSN: 2721-1371

Penggolongan daya tarik wisata yang dijelaskan dalam Peraturan Pemerintah Republik

Indonesia Nomor 50 Tahun 2011 tentang Rencana Induk Pembangunan Kepariwisataan Nasional Tahun 2010-2015, adalah sebagai berikut :

1. Daya Tarik Wisata Budaya

Daya tarik wisata budaya berupa hasil olah dan cipta, rasa dan juga karsa manusia sebagai makhluk budaya. Daya tarik ini bisa dibedakan menjadi dua, antara lain yang berwujud dan tidak berwujud. Daya tarik berwujud adalah seperti perkampungan tradisional, cagar budaya, tradisi dan adat masyarakat yang khas, ataupun museum. Sedangkan daya tarik yang tidak berwujud dapat berupa seperti kehidupan dan aktivitas masyarakat yang kaya akan budaya, dan juga kesenian seperti reog, angklung dan sebagainya.

2. Daya Tarik Wisata Alam

Daya tarik ini dapat dibedakan menjadi 2 yaitu daya tarik wisata alam berbasis potensi keanekaragaman lingkungan perairan laut seperti pesisir pantai, kolam air, bentang laut dan dasar laut. Adapun daya tarik wisata alam berbasis keanekaragaman wilayah daratan seperti hutan alam atau taman nasional, pegunungan, sungai, danau, perkebunan, pertanian, dan juga bentang alam khusus seperti padang pasir, gua dan sejenisnya.

3. Daya Tarik Wisata Buatan Manusia

Daya tarik ini diklasifikasikan sebagai daya tarik wisata khusus yang merupakan kegiatan manusia atau pun kreasi artifisial di luar wisata alam dan budaya. Daya tarik ini meliputi fasilitas rekreasi dan hiburan, olahraga dan peristirahatan ataupun taman bertema.

The World Tourism Organization (WTO), mendefinisikan aktivitas wisata sebagai kegiatan manusia yang melakukan perjalanan (keluar dari lingkungan asalnya) untuk tidak lebih dari satu tahun berlibur, berdagang, atau urusan lainnya. Menurut Stankovic dan Dukic (2009) aktivitas wisata merupakan keseluruhan aktivitas yang terdapat dalam sebuah objek wisata dan apa yang dapat dilakukan wisatawan selama waktu kunjungannya. Aktivitas wisata dapat berupa aktivitas rekreasi, kunjungan, mengunjungi teman atau kerabat, bisnis konvensi, festival, hiburan, belanja dan olahraga (Mcintosh et al dalam Neverterry(2010:41).

Menurut Barreto dan Giantari (2015: 11) pengembangan pariwisata merupakan suatu upaya untuk memajukan sebuah objek wisata agar objek wisata tersebut menjadi lebih baik dan lebih menarik jika dilihat dari segi lokasi, dan semua yang ada di dalam objek wisata tersebut sehingga dapat menarik minat wisatawan untuk mengunjungi objek wisata tersebut. Pengembangan sebuah daerah yang menjadi tujuan wisata sangat erat hubungannya dengan 
Edutourism Journal of Tourism Research I p-ISSN: 2686-4746 I e-ISSN: 2721-1371

pembangunan perekonomian suatu daerah atau suatu negara. Maka dari itu, pengembangan wisata merupakan alasan utama sebuah daerah tujuan wisata terus dikembangkan (Adikampana, 2017).

Pendekatan masyarakat (community approach) menjadi standar baku bagi proses pengembangan pariwisata di daerah pinggiran, dimana melibatkan masyarakat di dalamnya merupakan faktor yang sangat penting untuk menghasilkan kesuksesan terhadap produk wisata. Pariwisata berbasis kemasyarakatan atau Community Based Tourism merupakan salah satu konsep pengembangan suatu destinasi wisata lokal dimana masyarakat yang ada turut andil dalam perencanaan, pengelolaan dan juga memberi suara berupa keputusan dalam pembangunannya (Arifin, 2017). Prinsip dasar Community Based Tourism (CBT) menurut UNEP dan WTO (2005) adalah sebagai berikut :

1. Mengakui, mendukung dan mengembangkan kepemilikan komunitas dalam industri pariwisata.

2. Mengikutsertakan anggota komunitas dalam memulai setiap aspek.

3. Mengembangkan kebanggaan komunitas.

4. Mengembangkan kualitas hidup komunitas.

5. Menjamin keberlanjutan lingkungan.

6. Mempertahankan keunikan karakter dan budaya di area lokal.

7. Membantu berkembangnya pembelajaran tentang pertukaran budaya pada komunitas.

8. Menghargai perbedaan budaya dan martabat manusia.

9. Mendistribusikan keuntungan secara adil kepada anggota komunitas.

10. Berperan dalam menentukan presentase pendapatan (pendistribusian pendapatan) dalam proyek-proyek yang ada di komunitas.

\section{Metode Penelitian}

Jenis penelitian yang tim peneliti gunakan dalam penelitian ini adalah penelitian deskriptif kualitatif. Menurut Bogdan dan Taylor "metode kualitatif" sebagai prosedur penelitian yang menghadirkan data deskriptif beberapa kata kata tertulis atau lisan dari orang-orang atau pelaku yang dapat diamati (Moleong, 2018). Metode penelitian kualitatif biasanya mencakup wawancara dan observasi, tetapi mungkin juga termasuk studi kasus, survei, dan analisis historis dan dokumen. Penelitian deskriptif kualitatif bertujuan untuk menggambarkan, 
Edutourism Journal of Tourism Research I p-ISSN: 2686-4746 I e-ISSN: 2721-1371

melukiskan, menerangkan,menjelaskan dan menjawab secara lebih rinci permasalahan yang akan diteliti dengan mempelajari semaksimal mungkin seorang individu, suatu kelompok atau suatu kejadian (Mulyana, 2014) .

Menurut Sugiyono (2015:308) metode pengumpulan data diartikan sebagai cara ilmiah untuk mendapatkan data yang valid dengan tujuan dapat ditemukan, dikembangkan, dan dibuktikan, suatu pengetahuan tertentu sehingga pada gilirannya dapat digunakan untuk memahami, memecahkan, dan mengantisipasi masalah. Metode pengumpulan data yang digunakan pada penelitian pengembangan aktivitas wisata di Tebing Koja dilakukan dengan cara:

1. Wawancara

Wawancara menurut Sugiyono (2016:317) adalah teknik pengumpulan data untuk menemukan sebuah permasalahan baik terstruktur atau tidak terstruktur yang bisa dilakukan baik tatap muka atau via telepon. Tim penulis melakukan wawancara secara mendalam terhadap partisipan kunci yaitu pemilik asli dari objek wisata Tebing Koja.

2. Studi literatur

Studi literatur menurut Danial dan Warsiah (2009:80), merupakan penelitian yang dilakukan oleh seorang peneliti dengan cara mencari informasi melalui buku-buku, majalah yang berkaitan dengan topik masalah dan tujuan penelitian yang dibahas oleh peneliti tersebut. Tim penulis mengambil sumber-sumber dari literatur yang berkaitan untuk mendapatkan informasi yang dibutuhkan dalam penelitian ini, yang kemudian data tersebut akan dianalisis sehingga menghasilkan kesimpulan.

\section{Hasil dan Pembahasan}

Kota Tangerang dikenal dengan sebutan kota seribu industri. Karena kota ini merupakan pusat industri, kota bisnis perdagangan dan jasa (Ramadhiani, 2014). Tangerang yang merupakan kota terbesar di Banten, sangat besar kemungkinannya jika Tangerang menawarkan banyak lokasi alternatif untuk wisata, dan bukan hanya industri. Tidak hanya wisata modern, namun juga wisata alam, salah satunya adalah Tebing Koja yang merupakan objek wisata yang berlokasi di Desa Cikuya, Kecamatan Solear, Kabupaten Tangerang. Lokasinya sendiri lumayan jauh dari pusat kota, yaitu $42 \mathrm{~km}$ dari Kota Tangerang dan dapat ditempuh sekitar 1,5 jam. Tebing Koja jika dikaitkan dengan penggolongan daya tarik wisata yang dijelaskan dalam Peraturan Pemerintah Republik Indonesia Nomor 50 Tahun 2011 
Edutourism Journal of Tourism Research I p-ISSN: 2686-4746 I e-ISSN: 2721-1371

tentang Rencana Induk Pembangunan Kepariwisataan Nasional Tahun 2010-2015, adalah sebagai berikut :

1. Daya Tarik Wisata Budaya

Daya tarik wisata budaya yang terdapat di objek wisata ini adalah berupa spot foto yang berbentuk rumah adat baduy, namun dalam versi yang lebih kecil dan sederhana. Alasannya karena luas lahan yang cukup kecil dan juga agar wisatawan dapat memiliki potret rumah adat ini dalam jumlah yang banyak sebagai background. Selain rumah adat, makanan adat yang bercirikan Tangerang akan tersedia dalam waktu dekat di warungwarung yang dikelola oleh masyarakat di lokasi objek wisata ini.

2. Daya Tarik Wisata Alam

Daya tarik wisata alam, dapat dinikmati dengan pemandangan berupa persawahan, dan juga danau kecil yang terdapat di lokasi objek wisata dan sekitarnya. Selain itu, wisatawan pun dapat menikmati indahnya pemandangan berupa pegunungan yang nampak dari jauh setelah melakukan aktivitas hiking ke atas tebing terdahulu. Adapun sunset dan juga sunrise yang menambah daya tarik alam ketika berkunjung ke lokasi ini.

3. Daya Tarik Wisata Buatan Manusia

Daya tarik wisata buatan manusia dapat dinikmati langsung oleh wisatawan lewat objek utama di Tebing Koja, yakni tebing-tebing yang terbentuk atas dasar penambangan pasir sebelum dijadikan objek wisata seperti sekarang ini. Adapun jalur hiking yang sengaja dibuat untuk para pendaki dan juga rute jalan bagi pesepeda untuk sampai di puncak tebing sehingga wisatawan dapat menikmati pemandangan dari atas tebing tersebut.

Tebing Koja ini memberi sensasi pemandangan seperti suatu lembah yang dibawahnya terdapat hamparan sawah, danau kecil dan dikelilingi oleh tebing-tebing dan bukit-bukit pasir yang terbentuk secara alami dari sisa penggalian atau penambangan. Terdapat tebing yang menyerupai Godzilla yang merupakan salah satu daya tarik dari objek wisata Tebing Koja ini. Sebab bentuk uniknya yang mirip dengan taman purba, masyarakat sekitar menjuluki Tebing Koja dengan sebutan Tebing Koja Godzilla. Selain itu, adapun daya tarik lain seperti banyak tebing batu yang menyerupai gapura masuk, dan di bagian bawah terdapat danau kecil dimana wisatawan bisa menikmatinya sambil menaiki sebuah perahu. Adapun ladang sayur, sawah serta formasi batuan kapur yang menambah kekhasan objek wisata ini. 
Tidak hanya itu terdapat pondok-pondok kecil dan rumah adat yang menambah spot foto dan juga sebagai tempat berteduh wisatawan. Sehingga wisatawan memanfaatkan keunikankeunikan tersebut sebagai background / spot foto. Tidak hanya para wisatawan saja, cukup banyak yang memanfaatkan objek wisata tersebut sebagai lokasi foto prewedding mereka. Dilengkapi dengan indahnya persawahan dan juga kebun yang ada di sekeliling, menambah minat para wisatawan untuk berkunjung untuk melepas penat kota ataupun untuk menambah koleksi foto Instagram. Selain dari itu Tebing Koja dijadikan lokasi untuk melakukan aktivitas outdoor seperti hiking dan juga bersepeda. Meskipun lokasi ini lebih terkenal untuk ber swafoto dan bersantai, narasumber menjelaskan sebelum menjadi Tebing Koja tempat ini merupakan tempat hiking dan sekarang dibuatkan rute untuk bersepedah. Ada 2 rute yang bisa digunakan, rute yang lebih mudah dan aman sehingga cocok dengan pemula, serta ada juga rute yang terjal yang cocok untuk yang lebih berpengalaman. Ada beberapa kendala yang dikeluhkan oleh para wisatawan saat berwisata di objek wisata Tebing Koja ini, yaitu sebagai berikut:

1. Berdasarkan Narasumber pungli di kawasan Tebing Koja sudah mulai berkurang jika dibandingkan saat awal objek ini dibuka. Meskipun begitu, masih ada pungli yang terjadi seperti menagih uang yang lebih dariyang ditentukan oleh tim pengelola wisata, dikarenakan kepemilikan lahan yang lebih dari satu pihak.

2. Tebing Koja merupakan objek wisata yang termasuk baru maka dari itu fasilitas yang tersedia masih sangat terbatas dan sederhana. Sehingga wisatawan kurang nyaman dengan fasilitas umum di objek wisata.

3. Kurangnya pengaman seperti pembatas ataupun peralatan keamanan lainnya, membuat objek wisata ini terbatas terhadap umur tertentu para wisatawan, dan butuh pengawasan

orang tua yang lebih hati-hati bagi anak-anak yang bermain di objek wisata ini.

4.Spot foto yang ditawarkan kurang banyak karena area ini dimiliki oleh PT lain, sehingga hanya tersedia 4 lokasi utama dalam pengambilan gambar wisatawan. Selain dari itu, membutuhkan kekreatifitasan para wisatawan untuk menemukan spot foto.

Tebing Koja tidak terbentuk secara alami dan juga tidak dibuat dengan sengaja untuk menjadikannya sebuah objek wisata. Menurut narasumber, "Kandang Godzilla" ini 
Edutourism Journal of Tourism Research I p-ISSN: 2686-4746 I e-ISSN: 2721-1371

merupakan lokasi penambangan pasir dan tuf dimana penggalian lahan ini dimulai pada tahun 2009 sampai 2015 dan lahan ini merupakan lahan milik pribadi dan dikelola oleh keluarga dari pemilik lahan yang merupakan warga desa tersebut. Luas dari lahan tersebut sekitar 3 sampai 4 hektar. Pada awalnya lokasi ini merupakan lahan kapur yang datar, kemudian secara berangsur atau bertahap dilakukan penambangan pasir secara manual menggunakan cangkul, sehingga ada bagian keras yang tidak dapat digali hingga akhirnya aktivitas penambangan diberhentikan pada tahun 2015, yang menyisakan tebing-tebing batu yang bentuknya tidak beraturan tetapi terlihat indah (Rudi, 2021). Selanjutnya pemilik menjadikannya objek wisata saat tahun 2017, karena lokasi ini dibuat viral oleh pemudapemuda yang tidak sengaja memposting keindahan alam di Tebing Koja "Kandang Godzilla".

Fasilitas di objek wisata ini masih sangat terbatas. Diantaranya terdapat beberapa lahan parkir yang cukup luas, karena objek wisata ini memiliki beberapa pintu masuk, tetapi terdapat lahan parkir yang dijadikan sebagai pintu masuk utama. Selain lahan parkir yang dikelola oleh masyarakat sekitar, terdapat warung sederhana yang juga dikelola oleh masyarakat di area lokasi objek wisata ini, yang dapat membantu memenuhi kebutuhan para wisatawan, dan tentunya toilet umum. Masyarakat di sekitar wisata Tebing Koja ikut berpartisipasi dalam pengelolaan wisata ini. Bentuk partisipasi masyarakat sangat banyak dilakukan oleh masyarakat sekitar lingkungan Tebing Koja yaitu sebagai pedagang di warung-warung makanan yang mereka buka, seperti ketupat, air kelapa, minuman, dan berbagai makanan lainnya, mengelola toilet umum berbayar, lahan parkir, dan juga pemeliharaan objek wisata. Objek wisata ini sangat membantu perekonomian mereka sehari hari. Mereka memanfaatkan Tebing Koja ini sebagai lahan pendapatan mereka, dengan diberikan izin oleh pemilik untuk membuka warung makan sebagai bagian pendukung dari objek wisata, dan juga ikut dalam pengelolaan serta membantu dalam menjaga kebersihan objek wisata itu sendiri. Selain membantu perekonomian warga sekitar, wisatawan pun banyak menerima manfaat dari para masyarakat sekitar untuk memenuhi kebutuhan mereka dalam berwisata.

Dengan adanya objek wisata Tebing Koja tidak hanya memberikan manfaat bagi pemiliknya dan para pengunjung, akan tetapi juga memberikan manfaat bagi masyarakat yang ada di sekitar objek wisata tersebut. Oleh karena itu, masyarakat di sekitar objek wisata Tebing Koja sangat mendukung adanya objek wisata ini. Manfaat yang paling bisa dirasakan oleh masyarakat sekitar adalah dengan adanya objek wisata Tebing Koja, mereka dapat 
Edutourism Journal of Tourism Research | p-ISSN: 2686-4746 I e-ISSN: 2721-1371

mencari nafkah dengan berjualan di sekitar objek wisata tersebut. Menurut pemilik sekaligus pengelola objek wisata ini, kunjungan wisatawan meningkat di sekitaran tahun 2017 sampai dengan 2020. Namun objek wisata ini sempat ditutup dikarenakan kondisi pandemi dan kebijakan pemerintah. Tetapi akhir-akhir ini wisatawan mulai kembali berdatangan dengan kondisi yang paling ramai di akhir pekan. Untuk itu, Pemilik sekaligus pengelola wisata Tebing Koja sebagai narasumber, mengutarakan terkait upaya-upaya dan juga rencana yang akan dilakukan baik dalam waktu dekat maupun untuk waktu yang belum ditentukan,

1. Tebing Koja dibagi menjadi 2 pemilik, yaitu oleh sebuah PT dan juga yang dimiliki oleh keluarga Narasumber sendiri. Hal ini menyebabkan aktivitas pengembangan mengalami sedikit kendala akibat kurangnya komunikasi dan kerja sama antara pihak pemilik tanah. Untuk itu, menjalin kerja sama yang baik adalah inisiasi dalam proses pengembangan objek wisata ini.

2. Akibat dampak banjir di awal tahun 2020, terjadi kerusakan pada sebagian fasilitas di objek wisata, sehingga pemilik ingin melakukan beberapa perbaikan pada fasilitas maupun sarana prasarana yang terdapat disana dan lainnya. Misalnya, terowongan bambu yang sempat runtuh. Maka dari itu akan diperbaiki kembali. Kemudian pengembangan objek wisata menjadi rencana utama pengelola objek wisata ini, agar wisatawan dapat lebih merasa aman dan nyaman mengingat fasilitas yang disediakan masih bersifat sederhana, sehingga butuh banyak perbaikan dan juga pengembangan.

3. Pengelola Tebing Koja pun ingin menata ulang para penjual makanan dan minuman di sekitaran objek wisata, dengan tujuan pengelola ingin mengenalkan kepada wisatawan makanan dan minuman khas dari daerah tersebut.

4. Narasumber juga membahas bahwa Tebing Koja ingin menerapkan pariwisata berkelanjutan. Hal yang dilakukan pun masih sangat sederhana, seperti membuang sampah pada tempatnya dan juga rutin membersihkan dan merapikan rumput-rumput di sekitar lokasi objek wisata. Selain itu, pemilik juga menghimbau agar wisatawan tidak merusak atraksi yang ada di lokasi, agar objek wisata ini dapat berkelanjutan.

5. Di bagian usaha promosi, dapat terealisasi melalui sosial media seperti Instagram, Facebook dan sosial media lainnya dengan tujuan untuk mempertahankan eksistensi dari objek wisata Tebing Koja ini di mata masyarakat baik masyarakat sekitar Kabupaten Tangerang maupun dariluar Kota.

Berdasarkan hasil wawancara dengan narasumber, dapat disimpulkan masyarakat di objek 
Edutourism Journal of Tourism Research I p-ISSN: 2686-4746 I e-ISSN: 2721-1371

wisata Tebing Koja saat ini turut andil dalam keberlangsungan wisata, jika dikaitkan dengan prinsip dasar Community Based Tourism (CBT) menurut UNEP dan WTO (2005), adalah sebagai berikut:

1. Mengakui, mendukung dan mengembangkan kepemilikan komunitas dalam industri pariwisata.

2. Mengikutsertakan anggota komunitas dalam memulai setiap aspek.

3. Mengembangkan kebanggaan komunitas.

4. Mengembangkan kualitas hidup komunitas.

5. Menjamin keberlanjutan lingkungan.

6. Mempertahankan keunikan karakter dan budaya di area lokal.

7. Membantu berkembangnya pembelajaran tentang pertukaran budaya pada komunitas.

8. Menghargai perbedaan budaya dan martabat manusia.

9. Mendistribusikan keuntungan secara adil kepada anggota komunitas.

10. Berperan dalam menentukan persentase pendapatan (pendistribusian pendapatan) dalam proyek-proyek yang ada di komunitas.

Berdasarkan prinsip dasar Community Based Tourism (CBT), masyarakat di sekitar Tebing Koja terbukti turut andil dalam pengembangan dan pemeliharaan objek wisata Tebing Koja dengan cara melakukan beberapa hal, sebagai berikut:

1. Masyarakat di sekitar wisata Tebing Koja membantu mempromosikan objek wisata Tebing Koja kepada para wisatawan dengan cara menjadi pemandu wisata lokal sehingga membantu terjadinya pertukaran budaya.

2. Masyarakat di sekitar wisata Tebing Koja ikut terlibat dalam memberikan pemenuhan kebutuhan para wisatawan dengan memberikan konsumsi untuk wisatawan dengan cara membuka warung-warung makanan dan minuman, mengelola toilet umum berbayar, dan penyediaan lahan parkir.

3. Masyarakat di sekitar wisata Tebing Koja membantu dalam hal pemeliharaan objek wisata Tebing Koja dengan cara membantu dalam menjaga kebersihan objek wisata itu sendiri dengan melakukan gotong royong dan juga menjaga dalam bidang keamanan dalam membersihkan objek wisata Tebing Koja. 


\section{Kesimpulan}

Potensi wisata di Tebing Koja banyak memanfaatkan objek wisatanya. Salah satunya pemandangan lembah yang terdapat hamparan sawah, danau kecil dan dikelilingi oleh tebing dan bukit pasir. Salah satu daya tarik di Tebing Koja adalah tebing yang menyerupai Godzilla. Selain itu, adapun daya tarik lain seperti tebing batu yang menyerupai gapura masuk, telaga, ladang sayur, sawah serta formasi batuan kapur, pondok-pondok kecil dan rumah adat yang menambah spot foto dan juga tempat untuk wisatawan berteduh. Masyarakat di sekitar wisata Tebing Koja ikut berpartisipasi dalam pengelolaan wisata ini. Bentuk partisipasi masyarakat sangat banyak dilakukan oleh masyarakat sekitar lingkungan Tebing Koja yaitu sebagai pedagang, petugas parkir, dan juga pemeliharaan objek wisata. Jika dikaitkan dengan teori komponen daya tarik wisata menurut Cooper yang saat ini tersedia di objek wisata Tebing Koja yaitu Attraction, Accessibility, Amenity, dan Ancillary Service sudah mulai tersedia namun masih terbatas. Daya tarik wisata Tebing Koja masih membutuhkan banyak perbaikan dan pengembangan. Adapun potensi community based tourism di Daya Tarik Wisata Tebing Koja ini dapat dikembangkan dengan memberdayakan masyarakat sekitar. 
6 Author's declaration

Authors' contributions and responsibilities

Write the contribution of each author here or mark the following column.

$\sqrt{ }$ The authors made substantial contributions to the conception and design of the study.

$\sqrt{ }$ The authors took responsibility for data analysis, interpretation, and discussion of results.

$\sqrt{ }$ The authors read and approved the final manuscript.

\section{Availability of data and materials}

$\sqrt{ }$ All data are available from the authors.

Competing interests

$\sqrt{ }$ The authors declare no competing interest. 


\section{Referensi}

1) Adikampana, I. M. (2017). Pariwisata Berbasis Masyarakat. Denpasar, Bali, Indonesia: Cakra Press. Retrieved from https://simdos.unud.ac.id/uploads/file pendidikan_1 dir/2380508977a611bbadb6e562e19 690b8.pdf

2) Arifin, A. P. (2017, May). Pendekatan Community Based Tourism Dalam Membina Hubungan Komunitas di Kawasan Kota Tua Jakarta. Jurnal Visi Komunikasi, 120. Retrieved from

3) https://publikasi.mercubuana.ac.id/files/journals/16/articles/1647/submission/original/1643674-1-SM.pdf

4) Awwaabiin, S. (2021, June 07). Studi Literatur: Pengertian, Ciri-Ciri, dan Teknik Pengumpulan Datanya. Retrieved from https://penerbitdeepublish.com/studiliteratur/\#2_Danial_dan_Warsinah

5) Awwaabiin, S. (2021, September 10). Pengertian Objek Penelitian: Macam, Prinsip dan Contoh Lengkap. Retrieved from https://penerbitdeepublish.com/objekpenelitian/\#Pengertian_Objek_Penelitian_Menurut $\underline{\text { Ahli }}$

6) Badan Pusat Statistik. (2020, February 03). Retrieved from Jumlah kunjungan wisman ke Indonesia Desember 2019 mencapai 1,38 juta kunjungan.: https://www.bps.go.id/pressrelease/2020/02/03/1711/jumlah-kunjungan-wisman-ke indonesia-desember-2019-mencapai-1-38-juta-kunjungan-.html

7) Barreto, M \& Giantari, K. (2015). Strategi Pengembangan Objek Wisata Air Panas Di Desa Marobo, Kabupaten Bobonaro, Timor Leste. Retrieved from https://ojs.unud.ac.id/index.php/EEB/article/download/15129/12268/

8) Harys, A. (2020, August 2020). Objek Penelitian. Retrieved from https://www.jopglass.com/objek-penelitian/

9) Materi, A. (2021, February 09). Pengertian Wawancara Menurut Para Ahli Terlengkap. Retrieved from https://materibelajar.co.id/pengertian-wawancara-menurutparaahli/\#Sugiyono

10) Moleong, L. J. (2018). Metodologi penelitian kualitatif / penulis, Prof. DR. Lexy J. Moleong, M.A. (edisi revisi). PT Remaja Rosdakarya.

11) Purba, E. (2017). Peran Masyarakat Lokal Dalam Meningkatkan Kunjungan Wisatawan Di Objek Wisata Makam Papan Tinggi Kabupaten Tapanuli Tengah. 4. Retrieved from https://repositori.usu.ac.id/bitstream/handle/123456789/6127/142204024.pdf?sequence=1\&i sAllowed=y\#: :text=Masyarakat\%20lokal\%20sebagai\%20pengelola\%20dan,di\%20destinas i\%20Makam\%20Papan\%20Tinggi.\&text=Kunjungan\%20wisatawan\%20juga\%20berdampa k\%20pada\%20lingku 
12) Ramadhiani, A. (2014, Oktober 25). Tangerang Kota Seribu Industri dan Jasa. Retrieved from https://properti.kompas.com/read/2014/10/25/100544321/Tangerang.Kota.Seribu.Industri. dan.Jasa

13) Rudi. (2021, July 13). Retrieved from NativeIndonesia.com: https://www.nativeindonesia.com/tebing-koja-kandang-godzilla/

14) Soraya,S., Rahardjo, P., \& Herlambang, S. (2020, September 25). RENCANA PENGELOLAAN PARTISIPATIF OBJEK GEO WISATA Tebing Koja. Retrieved October 24, 2021, from https://journal.untar.ac.id/index.php/jstupa/article/download/8862/6469

15) Statistik Kependudukan Kabupaten Tangerang Tahun 2020. (2021). Kabupaten Tangerang, Banten, Tigaraksa: Dinas Kependudukan dan Pencatatan Sipil Kabupaten Tangerang. Retrieved from

https://tangerangkab.go.id/tangerangkabweb/files/statistik\%20kependudukan\%20 kab\%20tang\%202020.pdf

16) Setiawan, I. B. D. (2015). Identifikasi Potensi Wisata Beserta 4A (Attraction, Amenity, Accessibility, Ancilliary) Di Dusun Sumber Wangi, Desa Pemuteran, Kecamatan Gerokgak, Kabupaten Buleleng, Bali. 5-7. Retrieved from https://repositori.unud.ac.id/protected/storage/upload/penelitianSimdos/f3e2c92782684ae 4ee371072d490ae74.pdf 